\title{
PERLINDUNGAN PATEN TERHADAP SOFTWARE DAN APLIKASI ATAS HAK KEKAYAAN INTELEKTUAL
}

\author{
Devi Cantika \\ 155100018, 785567836 \\ Fakultas Komputer \\ devicantika.student@umitra.ac.id
}

\begin{abstract}
Paten sebagai konstruksi hukum memberikan perlindungan terhadap Software dan Aplikasi bagi penemuan yang memenuhi persyaratan paten, yaitu: unsur kebaruan dari penemuan dan perlindungan. Langkah inventif yang terkandung dalam penemuan; serta dapat atau tidaknya penemuan diterapkan dalam industri.

Untuk menciptakan kepastian perlindungan, hakim harus memperhatikan spesifikasi paten (dalam klaim) dan kebaruan penemuan tersebut di seluruh dunia, juga functionway-result test, terutama dalam kasus ini. Dalam pengajuan paten diwajibkan untuk mengungkapkan secara tepat unsur-unsur dari penemuan yang dimintakan perlindungan. Dengan demikian, dalam aplikasi hendaklah tertulis deskripsi tentang esensi dari penemuan. Ruang lingkup atau luasnya perlindungan paten tergantung pada klaim, klaim menunjukkan inti dari penemuan, sehingga untuk menilai pelanggaran paten tergantung pada interpretasi klaim, filing date, state of the art dan cakupan klaim paten terdahulu (prior art).
\end{abstract}

Kata Kunci : Pelindungan Paten, software dan aplikasi. 


\section{A. INTRODUCTION}

Paten yang dipakai dalam peraturan hukum Indonesia berasal dari bahasa Belanda octrooi dan octrooi berasal dari bahasa Latin dari kata auctor/auctorizare yang artinya dibuka. Maksudnya yaitu bahwa suatu penemuan yang mendapatkan paten menjadi terbuka dan untuk diketahui umum atas perlindungan Software dan Aplikasi. Hak Paten adalah hak yang diberikan pemerintah dan bersifat eksklusif. Hak eksklusif dari pemegang hak paten adalah produksi dari barang yang dipatenkan (manucfacturing) $\mathrm{p}$ enggunaan (using) dan

Penjualan (selling) dari barang tersebut dan perbuatanperbuatan yang berkaitan dengan penjualan barang seperti mengimpor dan menyimpan(stocking) seperti Software dan Aplikasi.

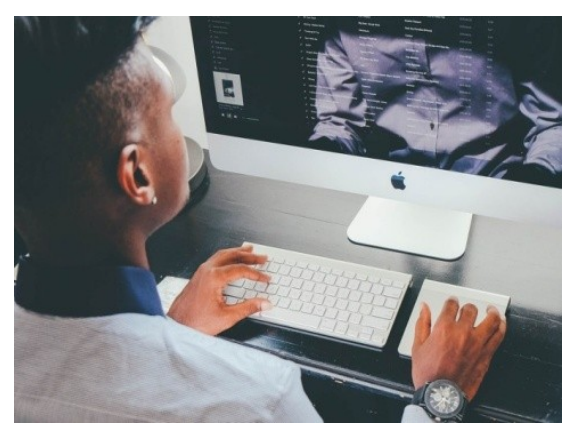

Di beberapa negara maju seperti Jepang dan Amerika Serikat perlindungan terhadap software dan Aplikasi dilakukan melalui paten. Meskipun demikian, sampai saat ini masih banyak perdebatan mengenai software yang dipantenkan di Amerika. Komunitas programmer dan ahli hukum menyatakan bahwa coding yang ada di dalam software dianalogikan sebagai "karya tulis" layaknya seorang novelis membuat sebuah novel. 
Di Indonesia, perlindungan software dilaksanakan melalui Hak Cipta. Perlindungan paten terhadap software belum diakui oleh pemerintah. Software atau program komputer dianggap sebagai sebuah ciptaan manusia dalam bidang ilmu pengetahuan komputer namun tidak berkaitan langsung dengan teknologi.

perlindungan software serta Applikasi berdasarkan undangundang di Indonesia, studi literatur yang membahas perlindungan software di dalam maupun luar negeri dan juga melakukan wawancara dengan lembaga perlindungan hak kekayaan intelektual di ITS untuk mendapatkan data empiris terkait dengan perlindungan software. Kami mencoba menganalisa implikasi dari perlindungan software terhadap masyarakat maupun pihak pengembang. Hasil dari penelitian ini diharapkan dapat

mengungkap

informasi tentang perlindungan software dan Aplikasi terhadap HAKI di Indonesia dan negara lainnya.

\section{Subyek paten}

Yang berhak memperoleh paten adalah penemu atau pihak yang menerima lebih lanjut hak penemu itu. Hal ini menegaskan bahwa hanya penemu atau pihak yang menerima lebih lanjut hak penemu yang yang berhak memperoleh paten atas penemuannya. Dalam kondisi tertentu suatu penemuan itu bisa lahir, misal karena pekerjaan kedinasan, kontrak kerja dan sebagainya. Menurut Undang-undang Nomor 14 Tahun 2001 tentang Paten pasal 11 sampai dengan pasal 15 diatur sebagai berikut :

a. Apabila penemuan dihasilkan oleh beberapa orang secara bersama-sama maka yang menerima lebih 
lanjut hak tersebut secara bersama-sama berhak atas penemuan tersebut.

b. Dalam suatu perjanjian kerja maka yang berhak memperoleh Paten suatu penemuan yang dihasilkan adalah orang-orang yang memberi pekerjaan kecuali diperjanjikan lain.

\section{Jenis-jenis paten}

Jenis-jenis paten yang dikenal saat ini yaitu :

1. Paten yang berdiri sendiri tidak bergantung pada paten lain (independent Patent)

2. Paten yang terkait dengan paten yang lainnya (dependent

Patent)

Keterkaitan bisa terjadi bila ada hubungan lisensi biasa maupun lisensi wajib dengan paten yang lainnya dan kedua paten itu dalam bidang yang berlainan 3. Paten Tambahan (patent of addition) atau paten perbaikan (Patentof
4. Paten import (Patent importation)

Paten ini bersifat khusus karena paten tersebut telah dikenal diluar negeri dan negara yang memberikan paten.

Di Indonesia menurut ketentuan Undang-undang Nomer 14 Tahun 2001 tentang paten, dibagi menjadi dua bentuk yaitu : 1. Paten biasa 2. Paten Sederhana

Suatu penemuan dikelompokkan menjadi paten sederhana karena penemuan tersebut tidak melalui proses penelitian dan pengembangan (research and development) yang mendalam. Paten sederhana hanya mempunyai hak untuk 1 klaim, pemeriksaan substantif langsung dilakukan tanpa permintaan dari pihak penemu. Hal ini berbeda dengan paten biasa yang melalui proses penelitian dan 
pengembangan (research

and development) yang

mendalam dan bisa

memiliki banyak hak untuk mengklaim.

\section{Perlindungan Hukum}

HakKekayaan Intelektual tentang Paten.

Masa berlakunya paten pada setiap negara berbeda-beda tergantung pada ketentuan UndangUndang yang berlaku dinegara yang bersangkutan. Perbedaan tersebut tergantung kondisi perekonomian dan peraturan yang berlaku. Di Indonesia menurut ketentuan Undang-Undang Nomor 14 Tahun 2001 tentang paten jangka pasal 8 ayat (1) waktu perlindungannya selama 20 tahun sejak tanggal penerimaan dan tidak bisa diperpanjang. Dan pasal 9 mengatur jangka waktu perlindungan untuk paten sederhana selama 10 (sepuluh ) tahun dan tidak dapat diperpanjang.

\section{a. Pengalihan paten}

Hak paten sebagai hak milik dapat dialihkan baik seluruhnya atau sebagian melalui beberapa cara :

a. Pewarisan

b. Hibah

c. Wasiat

d. Perjanjian (perjanjian lisensi)

e. Yang dibenarkan menurut Undang-Undang Segala bentuk pengalihan ini wajib didaftarkan pada Direktorat Jenderal Hak Kekayaan Intelektual dan dicatat dalam daftar umum paten, apabila tidak didaftarkan maka proses pengalihan tersebuttidak syah dan batal demi hukum. Pengalihan paten tidak menghapus hak penemu (hak inventor) untuk tetap dicantumkan nama dan identitasnya 


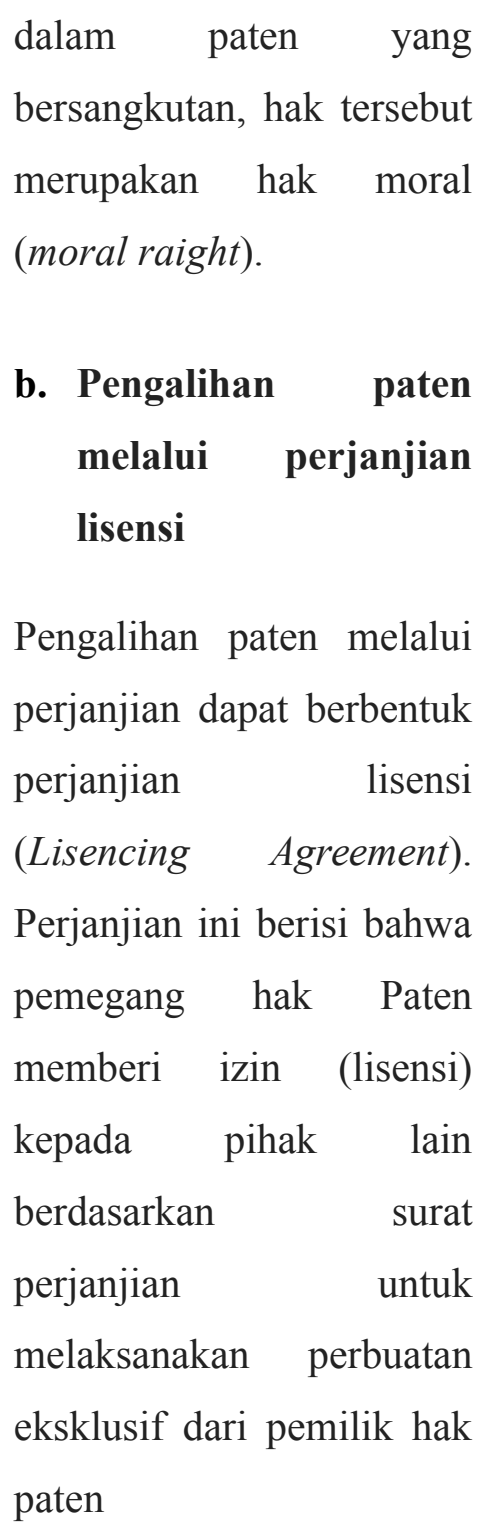

B. CONTENT

Di beberapa negara maju seperti Jepang dan Amerika Serikat perlindungan terhadap software dan Apliksi dilakukan melalui paten. Meskipun demikian, sampai saat ini masih banyak perdebatan mengenai software dan Aplikasi yang dipantenkan di Amerika. Komunitas programmer dan ahli hukum menyatakan bahwa coding yang ada di dalam software dianalogikan sebagai "karya tulis" layaknya seorang novelis membuat sebuah novel.

Di Indonesia, perlindungan software dilaksanakan melalui Hak Cipta. Perlindungan paten terhadap software belum diakui oleh pemerintah. Software atau program komputer dianggap sebagai sebuah ciptaan manusia dalam bidang ilmu pengetahuan komputer namun tidak berkaitan langsung dengan teknologi.

perlindungan software berdasarkan undang-undang di Indonesia, studi literatur yang membahas perlindungan software di dalam maupun luar negeri dan juga melakukan 
wawancara dengan lembaga perlindungan hak kekayaan intelektual di ITS untuk mendapatkan data empiris terkait dengan perlindungan software. Kami mencoba menganalisa implikasi dari perlindungan software terhadap masyarakat maupun pihak pengembang. Hasil dari penelitian ini diharapkan

dapat mengungkap

informasi tentang implikasi dari perlindungan software di Indonesia dan negara maju.

\section{c. CONCLUSION}

Berdasarkan penjabaran di atas dapat disimpulkan bahwa belum ada implikasi yang signifikan tentang perlindungan software di Indonesia. Lain halnya dengan negara maju seperti Amerika Serikat, perlindungan terhadap software mendapat perhatian yang cukup besar dari berbagai pihak dan menuai.
1. Perlindungan Software di Indonesia Berdasarkan Undangundang No.19 Tahun 2002 pasal 12, program komputer atau software termasuk dalam perlindungan Hak Cipta, bukan dengan paten. Perlindungan paten terhadap software hanya ada di negara-negara maju seperti Jepang dan Amerika Serikat. Hal ini diungkapkan pula oleh Prof. Soeprapto selaku Ketua BP2KI di ITS, perlindungan paten terhadap software belum ada di Indonesia.

perlindungan software serta Applikasi berdasarkan undangundang di Indonesia, studi literatur yang membahas perlindungan software di dalam maupun luar negeri dan juga melakukan wawancara dengan lembaga perlindungan hak kekayaan intelektual di ITS untuk mendapatkan data 
empiris terkait dengan perlindungan software. Kami mencoba menganalisa implikasi dari perlindungan software terhadap masyarakat maupun pihak pengembang. Hasil dari penelitian ini diharapkan dapat mengungkap

informasi tentang perlindungan software dan Aplikasi terhadap HAKI di Indonesia dan negara lainnya.

\section{Perlindungan Software di}

\section{Indonesia}

Berdasarkan Undang-undang No.

19 Tahun 2002 pasal 12, program komputer atau software termasuk dalam perlindungan Hak Cipta, bukan dengan paten. Perlindungan paten terhadap software hanya ada di negaranegara maju seperti Jepang dan Amerika Serikat. Hal ini diungkapkan pula oleh Prof. Soeprapto selaku Ketua BP2KI di ITS, perlindungan paten terhadap software belum ada di Indonesia. Pengertian dari paten sendiri adalah hak eksklusif yang diberikan oleh Negara kepada Inventor atas hasil Invensinya di bidang teknologi.

\section{DISCUSSION}

Hasil diskusi dari materi ini adalah Paten diberikan untuk Invensi yang baru dan mengandung langkah inventif serta dapat diterapkan dalam industri. Dimana Perlindungan Paten Terhadap Software Dan Aplikasi Atas Hak Kekayaan Intelektual, Suatu Invensi dikatakan mengandung langkah inventif jika Invensi tersebut merupakan sesuatu yang baru atau hal yang tidak dapat diduga sebelumnya menurut orang-orang yang mempunyai keahlian tertentu di bidang teknik. Penilaian bahwa suatu invensi merupakan hal yang tidak dapat diduga sebelumnya harus dilakukan dengan memperhatikan keahlian yang 
ada pada saat Permohonan diajukan.

\section{Perangkat Lunak Berpemilik}

Perangkat lunak berpemilik (propriety) ialah perangkat lunak yang tidak bebas atau pun semi-bebas. Seseorang dapat dilarang, atau harus meminta izin, atau akan dikenakan pembatasan lainnya sehingga menyulitkan - jika menggunakan, mengedarkan, atau memodifikasinya.

\section{Perangkat Komersial}

Perangkat lunak komersial adalah perangkat lunak yang dikembangkan oleh kalangan bisnis untuk memperoleh keuntungan dari penggunaannya. "Komersial" dan "Kepemilikan" adalah dua hal yang berbeda! Kebanyakan perangkat lunak komersial adalah berpemilik, tapi ada perangkat lunak bebas komersial, dan ada perangkat lunak tidak bebas dan tidak komersial. Sebaiknya, istilah ini tidak digunakan.

\section{E. REFERENCE}

[1] O. M. Febriani and A. S. Putra, "Sistem Informasi Monitoring Inventori Barang Pada Balai Riset Standardisasi Industri Bandar Lampung," J. Inform., vol. 13, no. 1, pp. 90-98, 2014.

[2] A. S. Putra, "Paperplain: Execution Fundamental Create Application With Borland Delphi 7.0 University Of Mitra Indonesia," 2018.

[3] A. S. Putra, "2018 Artikel Struktur Data, Audit Dan Jaringan Komputer," 2018.

[4] A. S. Putra, "ALIAS MANAGER USED IN DATABASE DESKTOP STUDI CASE DB DEMOS."

[5] A. S. Putra, "COMPREHENSIVE SET OF PROFESSIONAL FOR DISTRIBUTE COMPUTING."

[6] A. S. Putra, "DATA ORIENTED RECOGNITION IN BORLAND DELPHI 7.0."

[7] A. S. Putra, "EMBARCADERO DELPHI XE 2 IN GPUPOWERED FIREMONKEY APPLICATION."

[8] A. S. Putra, "HAK ATAS KEKAYAAN INTELEKTUAL DALAM DUNIA TEKNOLOGY BERBASIS REVOLUSI INDUSTRI 4.0."

[9] A. S. Putra, "IMPLEMENTASI 
PERATURAN

PERUNDANGAN UU. NO 31

TAHUN 2000 TENTANG

DESAIN INDUSTRI

BERBASIS INFORMATION TECHNOLOGY."

A.

S.

Putra,

"IMPLEMENTATION OF

PARADOX DBASE."

[11]

A. S Putra

"IMPLEMENTATION OF

TRADE SECRET CASE

STUDY SAMSUNG MOBILE PHONE."

[12] A. S. Putra, "IMPLEMENTATION

PATENT FOR APPLICATION

WEB BASED CASE STUDI

WWW. PUBLIKLAMPUNG. COM."

[13] A.

"IMPLEMENTATION

SYSTEM FIRST TO INVENT

IN DIGITALLY INDUSTRY."

[14] A. S. Putra, "MANUAL

REPORT \& INTEGRATED

DEVELOPMENT

ENVIRONMENT BORLAND

DELPHI 7.0."

[15] A. S. Putra, "PATENT AS RELEVAN SUPPORT RESEARCH."

[16] A. S. Putra, "PATENT FOR RESEARCH STUDY CASE OF APPLE. Inc."

[17] A. S. Putra, "PATENT PROTECTION FOR APPLICATION INVENT."

[18] A. S. Putra, "QUICK REPORT IN PROPERTY PROGRAMMING."

[19] A. S. Putra, "REVIEW CIRCUIT LAYOUT COMPONENT REQUIREMENT ON ASUS
NOTEBOOK."

[20] A. S. Putra, "REVIEW TRADEMARK PATENT FOR INDUSTRIAL TECHNOLOGY BASED 4.0."

[21] A. S. Putra, "TOOLBAR COMPONENT PALLETTE IN OBJECT ORIENTED PROGRAMMING."

[22] A. S. Putra, "WORKING DIRECTORY SET FOR PARADOX 7."

[23] A. S. Putra, "ZQUERY CONNECTION

IMPLEMENTED

PROGRAMMING STUDI CASE PT. BANK BCA Tbk."

[24] A. S. Putra, D. R. Aryanti, and I. Hartati, "Metode SAW (Simple Additive Weighting) sebagai Sistem Pendukung Keputusan Guru Berprestasi (Studi Kasus: SMK Global Surya)," in Prosiding Seminar Nasional Darmajaya, 2018, vol. 1, no. 1, pp. 85-97.

[25] A. S. Putra and O. M. Febriani, "Knowledge Management Online Application in PDAM Lampung Province," in Prosiding International conference on Information Technology and Business (ICITB), 2018, pp. 181-187.

[26] A. S. Putra, O. M. Febriani, and B. Bachry, "Implementasi Genetic Fuzzy System Untuk Mengidentifikasi Hasil Curian Kendaraan Bermotor Di Polda Lampung," SIMADA (Jurnal Sist. Inf. dan Manaj. Basis Data), vol. 1, no. 1, pp. 21-30, 2018.

[27] A. S. Putra, H. Sukri, and K. Zuhri, "Sistem Monitoring 
Realtime Jaringan Irigasi Desa (JIDES) Dengan Konsep Jaringan Sensor Nirkabel," IJEIS (Indonesian J. Electron. Instrum. Syst., vol. 8, no. 2, pp. 221-232.

[28] D. P. Sari, O. M. Febriani, and A. S. Putra, "Perancangan Sistem Informasi SDM Berprestasi pada SD Global Surya," in Prosiding Seminar Nasional Darmajaya, 2018, vol. 1, no. 1, pp. 289-294. 